\title{
39. Purification and Characterization of Arginine Kinase from Scallop Smooth Muscle
}

\author{
By Yoichi YazAWA \\ Department of Nutritional Physiology, Hokkaido University of \\ Education at Asahikawa, Hokkaido 070 \\ (Communicated by Setsuro EbashI, M. J. A., June 14, 1988)
}

Introduction. Arginine kinase, first discovered by Lohmann, ${ }^{1)}$ catalyzes the reversible formation of ATP and arginine from phosphoarginine and ADP:

phosphoarginine $+\mathrm{ADP}+\mathrm{H}^{+} \rightleftharpoons \mathrm{ATP}+$ arginine.

The reaction proceeding from left to right is arbitrarily designated as the forward reaction. The enzyme is found in a wide variety of invertebrate species, being especially abundant in muscle. In view of the function of phosphocreatine and creatine kinases in vertebrate muscles, it appears that arginine kinase also plays an important role in the contractile processes of invertebrate muscles. Little is known, however, about its precise physiological function. In this study, arginine kinase was prepared from scallop smooth muscle in a homogeneous state and some of its properties were described.

Materials and method. Unless otherwise stated, the following techniques were used to determine the activity of the enzyme. The activity of the forward reaction was determined according to the method of Morrison et al. ${ }^{2}$ ) Reaction mixture contained $0.45 \mathrm{ml}$ of $5 \mathrm{mM}$ phosphoarginine, $1 \mathrm{mM}$ ADP, $1 \mathrm{mM} \mathrm{MgCl}_{2}$ and $5 \mathrm{mM}$ MOPS buffer $(\mathrm{pH} 7.0)$. The tubes were incubated in a water bath at $25^{\circ} \mathrm{C}$ and the reaction was started by the addition of $0.05 \mathrm{ml}$ of arginine kinase solution. At the end of the incubation period the reaction was stopped by the addition of $0.5 \mathrm{ml}$ of $0.1 \mathrm{M} \mathrm{EDTA}-5 \mathrm{M} \mathrm{NaOH}$. The amount of arginine released during the reaction was determined in the same tube by the method utilizing Sakaguchi reaction ${ }^{3)}$ as described by Rosenberg et al.4) To the incubated mixture $3 \mathrm{ml}$ of water and $1 \mathrm{ml}$ of developing reagent were added and the red colored arginine complex was measured at $535 \mathrm{~nm}$ after standing for $30 \mathrm{~min}$ at room temperature. Developing solution contained $\alpha$-naphthol and diacetyl solubilized in ethanol; their final concentrations were $1 \%$ and $0.05 \%$, respectively. The velocity of the reverse reaction was estimated by measuring inorganic phosphate(Pi) released from phosphoarginine by acid hydrolysis. The reaction mixture, $0.4 \mathrm{ml}$, containing $10 \mathrm{mM}$ arginine, $5 \mathrm{mM}$ ATP, $10 \mathrm{mM} \mathrm{MgCl}_{2}$ and $5 \mathrm{mM}$ MOPS buffer ( $\mathrm{pH} 8.5$ ), was incubated in a water bath at $25^{\circ} \mathrm{C}$. The reaction was started by adding $0.1 \mathrm{ml}$ of enzyme solution and stopped by the addition of $0.5 \mathrm{ml}$ of $0.2 \mathrm{~N}$ TCA. The tubes were then placed in boiling water for 1 min. Under these conditions phosphoarginine is quantitatively hydrolyzed to arginine and inorganic phosphate. They were then rapidly cooled in an ice bath and liberated Pi was estimated by the method of Fiske and SubbaRow with a slight modification. ${ }^{5}$ )

Amino acid analysis was carried out essentially by the method of Moore and Stein $^{6}$ ) with a Hitachi amino acid analyzer (Model KLA-3B). Samples of the enzyme were hydrolyzed in costant boiling $\mathrm{HCl}(6 \mathrm{~N})$ in evacuated, sealed tubes for $24 \mathrm{~h}$. After evaporation of $\mathrm{HCl}$, hydrolyzates were dissolved in $\mathrm{pH} 2.2$ solution and analyzed. Total half-cystine was determined by measuring cysteic 


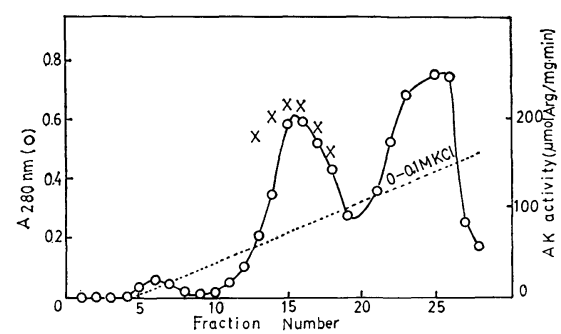

Fig. 1. Chromatography of the fraction precipitated between 0.72 and 0.95 saturated ammonium sulfate of $1 \mathrm{mM}$ EDTA extract from scallop smooth muscle. Crude arginine kinase fractionated with $\left(\mathrm{NH}_{4}\right)_{2} \mathrm{SO}_{4}(56 \mathrm{mg})$ was collected and dialyzed against $10 \mathrm{mM}$ Tris- $\mathrm{HCl}(\mathrm{pH} \mathrm{8.0)}$ and applied to a DEAEToyopearl column $(2.1 \times 8 \mathrm{~cm})$ equilibrated with the same buffer solution and eluated by using a linear gradient formed for $10 \mathrm{mM}$ Tris- $\mathrm{HCl}$ buffer ( $\mathrm{pH} \mathrm{8.0)}$ and $0.1 \mathrm{M} \mathrm{KCl}$ containing the same buffer. $\mathrm{KCl}$ concentration is shown as a dotted line. Each fraction is $4 \mathrm{ml}$. $\times$, kinase activity.

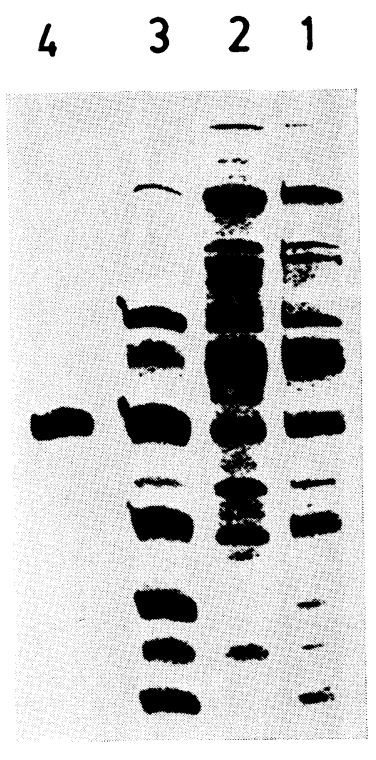

Fig. 2. SDS-PAGE patterns of fractions obtained during purification of arginine kinase. Electrophoresis was carried out using $10 \%$ polyacrylamide gel containing $0.1 \%$ SDS. Lane 1, $1 \mathrm{mM}$ EDTA extract from scallop smooth muscle. Lane 2 , the fraction precipitated by $72 \%$ saturation of $1 \mathrm{mM}$ EDTA extract. Lane 3, the fraction precipitated by $95 \%$ saturation of $1 \mathrm{mM}$ EDTA extract. Lane 4, arginine kinase (fraction number 15) purified by DEAE-Toyopearl column chromatography.

acid produced by performic acid oxidation. ${ }^{\pi}$ Tryptophan content was determined from the absorption spectrum of the enzyme dissolved in $6 \mathrm{M}$ guanidine- $\mathrm{HCl}$, pH 6.5, as described by Edelhoch. ${ }^{8)}$

SDS-PAGE (polyacrylamide gel electrophoresis) was performed according to the method of Porzio and Pearson. ${ }^{9)}$ The protein concentration was determined by biuret reaction ${ }^{10)}$ and also by the absorbance at $280 \mathrm{~nm}$.

Results and discussion. Adductor smooth muscle (45 g), obtained from living scallop, Patinopecten yessoensis, in the Sea of Okhotsk, was blended in 5 volumes of a solution containing $1 \mathrm{mM}$ EDTA and $10 \mathrm{mM}$ Tris- $\mathrm{HCl}$ buffer ( $\mathrm{pH} 8.0$ ), and extracted for $30 \mathrm{~min}$ at $4^{\circ} \mathrm{C}$. The mixture was centrifuged for 
Table I. Yields and specific activities of fractions obtained during purification of arginine kinase from scallop smooth muscle (started with $45 \mathrm{~g}$ muscle)

\begin{tabular}{ccccc}
\hline Fraction & Volume & Protein & $\begin{array}{c}\text { Specific activity } \\
(\mu \mathrm{mol} \mathrm{Arg} / \mathrm{mg} \cdot \mathrm{min})\end{array}$ & $\begin{array}{c}\text { Total } \\
\text { activity }\end{array}$ \\
\hline $\begin{array}{l}\text { Extract } \\
\text { Ammonium sulfate }\end{array}$ & 95 & $694 \mathrm{mg}$ & 7.3 & 5,059 \\
$\begin{array}{c}\text { precipitate } \\
\quad(0.72 \text { saturation) }\end{array}$ & 22 & 400 & 3.0 & 1,200 \\
$\begin{array}{c}\text { Ammonium sulfate } \\
\text { precipitate (0.72 } \\
\text { to 0.95 saturation) }\end{array}$ & 16 & 56 & 69.0 & 3,864 \\
Eluates & 25 & 17 & 210.0 & 3,570 \\
\hline
\end{tabular}

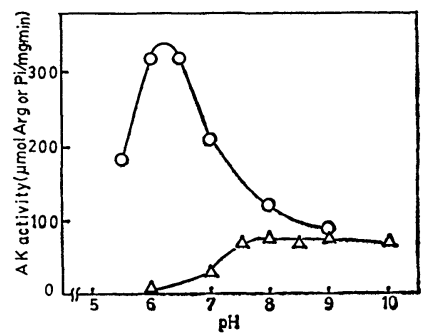

Fig. 3. Effects of all $\mathrm{pH}$ on the activities of the forward reaction $(O)$ and the reverse reaction $(\triangle)$ of arginine kinase. The forward and reverse reaction were carried out under the same assay conditions as described in "Materials and methods".

$10 \mathrm{~min}$ at $8,000 \mathrm{rpm}$ and to the resulting supernatant was added 0.1 volume of $0.5 \mathrm{M}$ Tris-HCl buffer ( $\mathrm{pH} 8.0$ ). The solution was then brought to 0.72 saturation by the addition of solid ammonium sulfate. The precipitate was removed by centrifuging at $13,000 \mathrm{rpm}$ for $10 \mathrm{~min}$ and the resulting supernatant was then brought to 0.95 saturation by further addition of solid ammonium sulfate. The precipitate was collected by centrifugation and dissolved in $10 \mathrm{mM}$ Tris- $\mathrm{HCl}$ buffer ( $\mathrm{pH}$ 8.0). The resulting solution was dialyzed for $18 \mathrm{hrs}$ against 2 changes of the same buffer. It was then applied to DEAE-Toyopearl column and eluated by using $\mathrm{KCl}$ linear gradient. As shown in Fig. 1, arginine kinase was eluted in the first peak. Fig. 2 shows SDS-PAGE patterns of fractions obtained in the course of purification. One of the fractions was shown to be homogeneous, its molecular weight being estimated to be $43 \mathrm{~K}$. The yields and specific activities of fractions during the purification are summarized in Table I.

Effects of $\mathrm{pH}$ on the kinase activity are shown in Fig. 3. The $\mathrm{pH}$-activity curve shows a broad optimum between 8 and 10 in the reverse reaction, resembling that of rabbit muscle type creatine kinase. The forward reaction involving proton shows a lower optimum between 6 and 6.5 as expected.

For rabbit muscle creatine kinase, $\mathrm{Mg}^{2+}, \mathrm{Mn}^{2+}, \mathrm{Ca}^{2+}$ and $\mathrm{Co}^{2+}$ have been found to act as activators. As shown in Fig. 4, the activity of arginine kinase in the forward reaction is markedly increased by $\mathrm{Mg}^{2+}$, but not by $\mathrm{Ca}^{2+}$ quite unexpectedly. $\mathrm{Mn}^{2+}$ and $\mathrm{Co}^{2+}$ also activated the enzyme. No activation was seen with $\mathrm{Ba}^{2+}, \mathrm{Sr}^{2+}, \mathrm{Ni}^{2+}, \mathrm{Fe}^{2+}, \mathrm{Cu}^{2+}$ and $\mathrm{Zn}^{2+}$ (data not shown). In the reverse reaction, $\mathrm{Mg}^{2+}, \mathrm{Mn}^{2+}$, and $\mathrm{Co}^{2+}$ activated the enzyme, but there was no activation by $\mathrm{Ca}^{2+}$ (data not shown). The enzymatic activity somewhat decreased with increase in $\mathrm{KCl}$ concentrations (about $60 \%$ of the maximum at $0.6 \mathrm{M})$. 


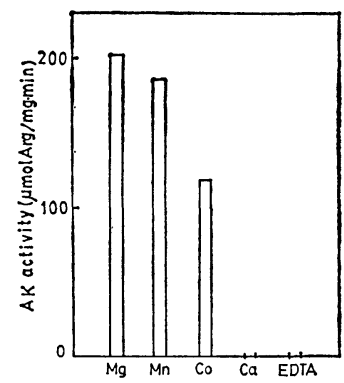

Fig. 4. Effects of metal ions on the arginine kinase activity in the forward reaction. Reaction mixtures and conditions were the same as described in "Materials and methods" except the presence of various metal ions of $1 \mathrm{mM}$ or $1 \mathrm{mM}$ EDTA.

Table II. Amino acid composition of arginine kinase ${ }^{* 1}$

\begin{tabular}{lcc}
\hline & Scallop & Lobster \\
\hline Asx & 44 & 38 \\
Thr & 17 & 17 \\
Ser & 20 & 16 \\
Glx & 33 & 39 \\
Gly & 35 & 28 \\
Ala & 28 & 25 \\
Val & 21 & 22 \\
Met & 10 & 8 \\
Ile & 16 & 17 \\
Leu & 37 & 28 \\
Tyr & 9 & 9 \\
Phe & 17 & 19 \\
Lys & 40 & 27 \\
His & 11 & 8 \\
Arg & 16 & 16 \\
Pro & 12 & 12 \\
Cys*2 & 9 & 5 \\
Trp*3 & 3 & 3 \\
\hline Total & 378 & 337 \\
\hline
\end{tabular}

*1 Values are mol of amino acid/mol of arginine kinase. The molecular weight of scallop arginine kinase was estimated to be 43,000 according to the pattern of SDS-PAGE and the values for lobster arginine kinase were derived Blethen et al. ${ }^{11)} * 2$ Determined as cysteic acid after perfomic acid oxidation and hydrolysis in $6 \mathrm{~N} \mathrm{HCl}$ for $18 \mathrm{hr}^{7}$ ) $* 3$ Determined by the spectrophotometric method of Edelhoch. ${ }^{8)}$

The amino acid composition of scallop arginine kinase was similar to that of lobster arginine kinase as shown in Table II. However, Lys, Leu and Cys contents of scallop arginine kinase were higher than those of lobster kinase. Smaller differences were observed among some other residues.

The phylogenetic significance of remarkable difference in distribution in the animal kingdom between arginine kinase and creatine kinase has long been a matter of discussion. To inquire into this problem, isolation and characterization of both enzymes from different kinds of species must be carried out before anything else. In this respect, the studies on arginine kinase have so far been very much behind those on creatine kinase. The development of a simple method of purifying arginine kinase in this article may be an important forward step in pursuing this interesting problem. 


\section{References}

1) Lohmann, K.: Biochem. Z., 282, 109 (1935).

2) Morrison, J. F., Griffiths, D. E., and Ennor, H. A.: Biochem. J., 65, 143 (1957).

3) Sakaguchi, M.: J. Biochem., 5, 25 (1925).

4) Rosenberg, H. A., Enorr, H., and Morrison, F.: Biochem. J., 63, 153 (1956).

5) Fiske, C. H., and SubbaRow, Y.: J. Biol. Chem., 66, 375 (1925).

6) Moore, S., and Stein, W. H.: Methods in Enzymology, 6, 819 (1963).

7) Moore, S.: J. Biol. Chem., 238, 235 (1963).

8) Edelhoch, H.: Biochemistry, 6, 1948 (1967).

9) Portzio, M. A., and Pearson, A. M.: Biochim. Biopys. Acta, 490, 27 (1977).

10) Goldberg, A., and Lehman, W.: Biochem. J., 171, 413 (1978).

11) Blethen, S. L., and Kaplan, N. O.: Biochemistry, 6, 1413 (1967). 